\title{
The Leadership Behavior of Madrasah Principals in Improving the Quality of Education in MAN 3 Medan
}

\author{
Muhammad Fuad Zaini' ${ }^{1}$, Syafaruddin ${ }^{2}$ \\ 1,2 Universitas Islam Negeri (UIN) Medan, Indonesia
}

Corresponding Author: M. Fuad Zaini $\otimes$ fuadzaini06@gmail.com*

\begin{tabular}{|c|c|}
\hline & ACT \\
\hline $\begin{array}{c}\text { ARTICLE INFO } \\
\text { Article history: } \\
\text { Received } \\
\text { February 18, } \\
2020 \\
\text { Revised } \\
\text { August 20, 2020 } \\
\text { Accepted } \\
\text { November } 21 \text {, } \\
2020\end{array}$ & $\begin{array}{l}\text { This article aimed to determine the existing leadership behavior in the } \\
\text { school as an effort to improve the quality of education by implementing } \\
\text { programs, communication, and motivation. This research used qualitative } \\
\text { methods in case study. The researchers used triangulation, observation, } \\
\text { interviews, and documentation in data collecting methods. The results } \\
\text { showed that the implementation of activity programs such as training can } \\
\text { improve the quality and professionalism of teachers. Coaching } \\
\text { extracurricular activities can add insight and soft skills to students. The } \\
\text { implementation of the Adiwiyata Dimadrasah program aimed at creating } \\
\text { awareness of loving the environment and as a place for learning. The } \\
\text { communication applied by the principal was interpersonal } \\
\text { communication, two-way, and feedback. The form of motivation towards } \\
\text { madrasah citizens was exemplified by performance, professional, } \\
\text { procedural and agents of change. }\end{array}$ \\
\hline ow to cite & $\begin{array}{r}\text { Keywords: Leadershi } \\
\text { Zaini, .M., \& Syafa } \\
\text { Principals in Impro }\end{array}$ \\
\hline & https://creativecommons.org \\
\hline
\end{tabular}

\section{INTRODUCTION}

Leadership is a provide ideas and be able to defend them by arguing ethically and rationally so that other people are encouraged to consider them, the ability to motivate other parties by using the most appropriate way and means so that all parties work together and in organizational unity obey the direction and coordination. Leadership is the ability someone has to influence others (Makawimbang, 2012). Nur (2016) argues that quality education is when internal customers (madrasah principals, teachers, and madrasah employees) improve their quality physically and mentally, while external customers, namely: primary external (students), external secondary (parents of government and company leaders), and external tertiary (community market) (Triyatna, Deni Kuswara, 2012). This implies that leadership is an individual ability to influence others so that others submit to or follow all the wishes of the leader, the ability to control more stable forms of cooperation and an increasingly productive process, through a monolithic selection of personnel.

An experimental study of school principals conducted by (Miller et al., 2016) rural areas in Michigan states that in teacher work activities, the involvement of the principal (top leader) is required so that an increase in teaching, practice, and knowledge and teacher confidence is obtained. The results showed that school principals in Qingdao, China have typical instructional leadership that affects teacher professional learning, 
the importance of self-efficacy in shaping teacher teaching practices (Liu \& Hallinger, 2018). Yunus (2016) explained that the professionalism of teachers at SDN 65 Katteong can be seen from 4 competency aspects; professional, pedagogic, personal, and social. Efforts can be made to improve teacher quality by involving scientific meetings, continuing studies informal institutions, participating in professional organizations, and participating in science competitions.

Further explained (Fitrah, 2017) in his research that a principal has a very complex role, this role includes managers, supervisors, educators, administrators, leaders, innovators, and motivators. Meanwhile, the quality of education cannot be separated from the attention of a madrasah principal to the performance of teachers, staff, and the school environment so that it gets the attention of stakeholders and the community. (Jones et al., 2015) in their research argued that the existence of policies carried out in Malaysia resulted in increased accountability of school principals added contemporary insights in practicing as school principals, and viewed leadership practices as transformational and distributed.

Another study mentions the leadership that Mts madrasah principals are trying to implement. Miftahul Falah Deli Serdang as an effort to improve the quality of education is a type of democratic leadership, which prioritizes deliberation on activities that occur in madrasas, deliberations are held with all teachers and staff to make decisions (Hasibuan et al., 2019). Another finding research by (Said, 2018) that the ability of a leader to improve the quality of education itself is loyal, guiding, motivating, providing comfort, service, directing, interacting, father figure, building networks, and being knowledgeable. In Islam itself, it is called the character of shiddiq, amanah, tabligh, fathanah. The success of madrasas in improving quality depends on the ability of the madrasah principal to take advantage of hard system tools in the form of strategies, structures, and soft system tools, namely share values, staff, skills, and styles. Thus it is known that a school principal plays a very important role in the smooth running of existing activities in every behavior education institution, the leadership model and character that is applied will greatly affect the conditions in the madrasah, whether the quality of the madrasah depends on the policies taken by a leader.

The results of research (Gurova et al., 2015) in Russia at this time, said that the quality of an educational institution is if schools can prove accountability to the public, empower consumers, be able to manage schools autonomously, provide appropriate wages and incentives for teacher performance. As well as evaluations carried out as a form of responsibility culture that must be published. Improvement the quality of education are seminars, upgrades, workshops, or training education. The training is expected to be able to provide innovation, strategy development, learning methods, evaluation, commitment (Continuous Quality Improvement), and assessment (Saifulloh et al., (2012). If the principal of a school/madrasah wants to improve the quality of education, he must carry out his strategic role as manager of educational institutions, have an idealistic attitude that can realize the vision, mission, and goals of the school, have intellectual skills and concern for members, and the ability to optimize all existing human resources. (Fadhli, 2019; Krisbiyanto, 2019). The head of the madrasah is a leader who has dignity, so it will be possible to get support from teachers, students, committees, and parents. So that to increase the professionalism of teachers and education personnel, management of infrastructure, and financing democratically, namely collaborating with teachers, committees, and parents (Maryati, 2016). Improving the quality of education means coaching the teachers and employees at the school, as for the form of leadership style carried out by the principal, namely the 
instructive leadership style (teachers or employees whose academic abilities and performance are lacking), consultative leadership styles (teachers or employees lack academics but good morale), participatory leadership (teachers or employees have good abilities but lack of morale) (Achmad, 2016).

The leadership applied by the head of the madrasah as the spearhead of progress in a madrasah, from various theories and research results prove that the patterns and behavior of leadership that are applied will also produce different results and determine the quality of education. There is a need for coaching, training, behavior improvement, decision making, and policies for the head of a madrasah to demonstrate their existence in the education arena. This research explores how the programs that are running in Madrasah Aliyah Negeri 3 Medan as a form of improving the quality of these madrasas, by obtaining " $\mathrm{A}$ " accreditation, whether the education quality criteria have been achieved. Observing how the leadership behavior of the head of the madrasah in communication motivates the madrasah. To obtain leadership behavior that should be carried out to improve the quality of education quality in madrasas.

\section{METHOD}

This study uses a qualitative method with a case study approach (Case Study), a case study, which is research on an individual, group, organization, specific institution (Sugiyono, 2016). Sources of data and informants in this study were school principals, vice-principals, administration (TU), and teachers in Madrasah Aliyah Negeri (MAN) 3 Medan. In collecting data, the researcher used observation, interview, and documentation. The data analysis technique was carried out by the stages of data reduction, data display, and conclusion/verification. To determine the validity of the data, the degree of trust (credibility), transferability, dependability, and certainty are used. The formulation of the problem in this study is how to implement the quality improvement program and the Communication Behavior and Motivation of the Head of Madrasah in MAN 3 Medan.

\section{RESEARCH RESULTS AND DISCUSSION}

The principal of madrasah has carried out several programs, namely conducting training programs for teachers as a solution, training which is intended, among others; competency training and curriculum innovation. MAN 3 Medan tries to optimize the quality of teachers by participating in competency training through the MGMP forum, where it is found that teachers can increase their existence, competence and foster creativity. Competence as a demand that must be met by teachers, for that teachers must continue to innovate so that competencies are more advanced and developing. 4 competencies must be achieved, namely: pedagogic competence, professionalism, attitudes and skills as benchmarks for teacher abilities. Because of this, the residents of the MAN 3 Medan madrasah either conduct training training by being managed by the madrasah, or attending education and training programs from the government. An effort to optimize efforts to implement the 2013 curriculum. Implementation will run well if the competencies of the teachers are also good and meet the criteria of the 4 competencies. Renewal is something that is the obligation of an institution that wants to be consistent in doing it. Innovation does not necessarily just rely on ideas, but there needs to be a SWOT evaluation and analysis of these ideas. Innovation for an institution is carried out because of changes in the culture of the community and the views and values that are adopted. For this reason, training / training for curriculum innovation was carried out by members of the MAN 3 Medan madrasah to strengthen 
understanding of the 2013 curriculum. From these various training and training teachers were able to apply K-13 effectively, efficiently, relevantly and productively, to encourage the achievement of educational goals.

Especially for students the efforts made by participating in science competitions, with the achievements achieved by students of MAN 3 Medan showing the students' competence in science, especially science competitions that are carried out at the provincial level of North Sumatra. The head of the madrasah in carrying out the madrasah work program is by providing extracurricular coaching, namely in the field of Nasyid which has performed well at the level of Medan City and North Sumatra province. Currently, the students are also doing mushroom cultivation. In marketing the mushrooms that are being cultivated in MAN 3, also collaborating with the North Sumatra KADIN through the Regional Office of the Ministry of Religion of North Sumatra. This received a response from the North Sumatra Regional Office of the Ministry of Religion, as explained by the Head of the North Sumatra Ministry of Religion, saying "Madrasah schools must be able to compete with public schools. To improve the quality of education in Madrasahs, there needs to be 3 Supporting Components including Support from the Government, Support from Schools and Committees, and Private Support ". Currently, the North Sumatra Regional Office of the Ministry of Religion has collaborated with the North Sumatra Province KADIN (Chamber of Commerce and Industry) in terms of developing the potential of Madrasah students by teaching entrepreneurship and marketing of products produced by Madrasas in North Sumatra.

\section{Figure 1. Environment MAN 3 Medan}

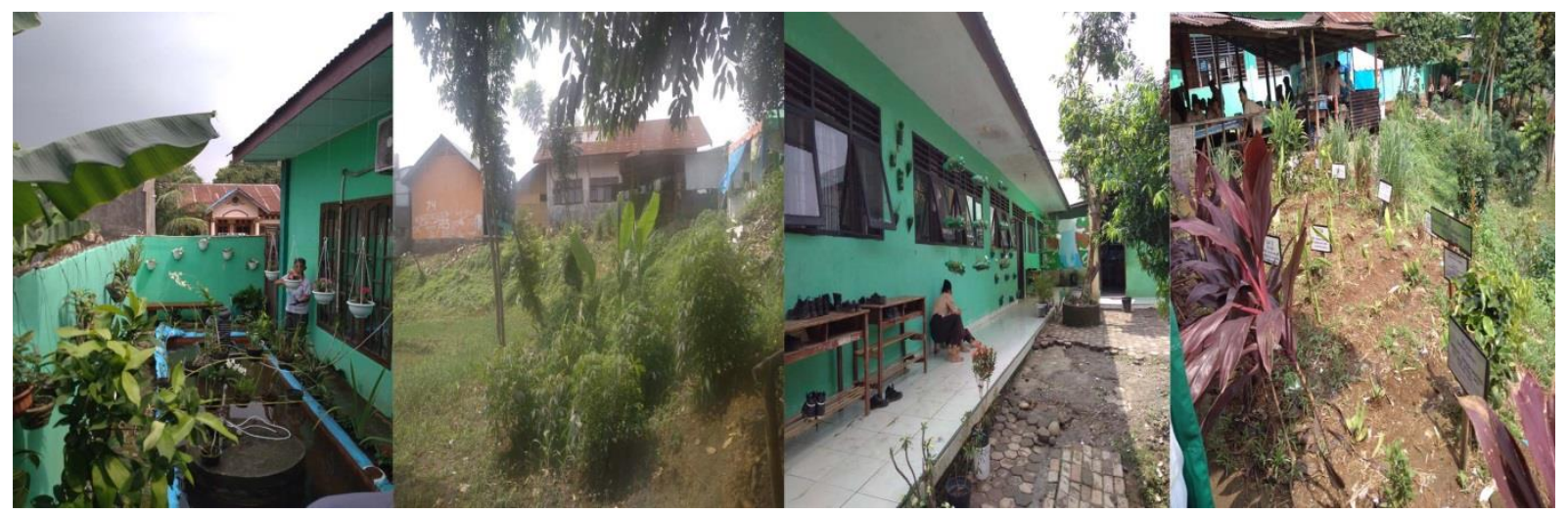

One of the programs currently running and a priority for MAN 3 Medan is Adiwiyata. This program is a priority for madrasah principals and is a program that will be contested in every madrasah. For the initial stage of the program, namely by establishing 8K (Security. Order, Cleanliness, Beauty, Kinship, Shelter, Health, and Harmony) besides that, weekly and daily routine activities, daily activities such as class pickets carried out by students and with Superintendent teachers or homeroom teachers, while weekly activities are carried out by all components of the madrasah, students, teachers, administrators, and even school principals. Members of the MAN 3 Medan madrasah develop the Adiwiyata program by creating a living pharmacy, environmental protection by planting trees and making shelter water for watering plants. The development of the Adiwiyata program is based on norms in life which include: togetherness, openness, equality, honesty, justice, and preservation of the functions of the environment and natural resources. The goal is to create good 
conditions for schools to become places of learning and awareness for madrasah citizens to take responsibility for efforts to save the environment and sustainable development. This program is also expected to be able to educate students about the importance of protecting the environment and participating so that the character of environmental awareness can be formed. There are several ways that madrasah principals make the Adiwiyata program effective, namely by; orientation of each subject towards the environment, through extracurricular activities, the role of parents towards students outside of school hours, socialization to committees, and the community.

\section{Communication Behavior and Motivation of Madrasah Principals in MAN 3 Medan}

The communication that the principal of the madrasah at MAN 3 Medan tries to implement is to help create an atmosphere of brotherhood, cooperation, with a full sense of freedom, and to give contributions to groups to coordinate all forms of madrasah programs. In its operation, the form of the headmaster's behavior in communicating reciprocally can generate feedback directly in response to a message. Two-way communication and direct feedback will allow for effective communication. In an organization, especially madrasah, the communication process is a process that is sure and always occurs. Communication is a means of coordinating between the various subsystems in madrasah. Good communication is characterized by synergistic and harmonious cooperation of various components. The better communication between the head of the madrasah and all madrasah members are believed to be able to improve the quality of education. The implementation of effective interpersonal communication at MAN 3 Medan will provide a comfortable atmosphere at work. If there is no openness in providing information both between the teacher and the teacher and the principal, it will affect each other's performance. Interactive communication patterns between superiors and subordinates and fellow colleagues can provide understanding and tolerance in an organization so that it can lead to good performance. Without communication within a school, the teacher will not know what information to do, and the principal will not get information from the teachers.

Figure 2. Interview with the principal of madrasah (left) and teacher (right) MAN 3 Medan

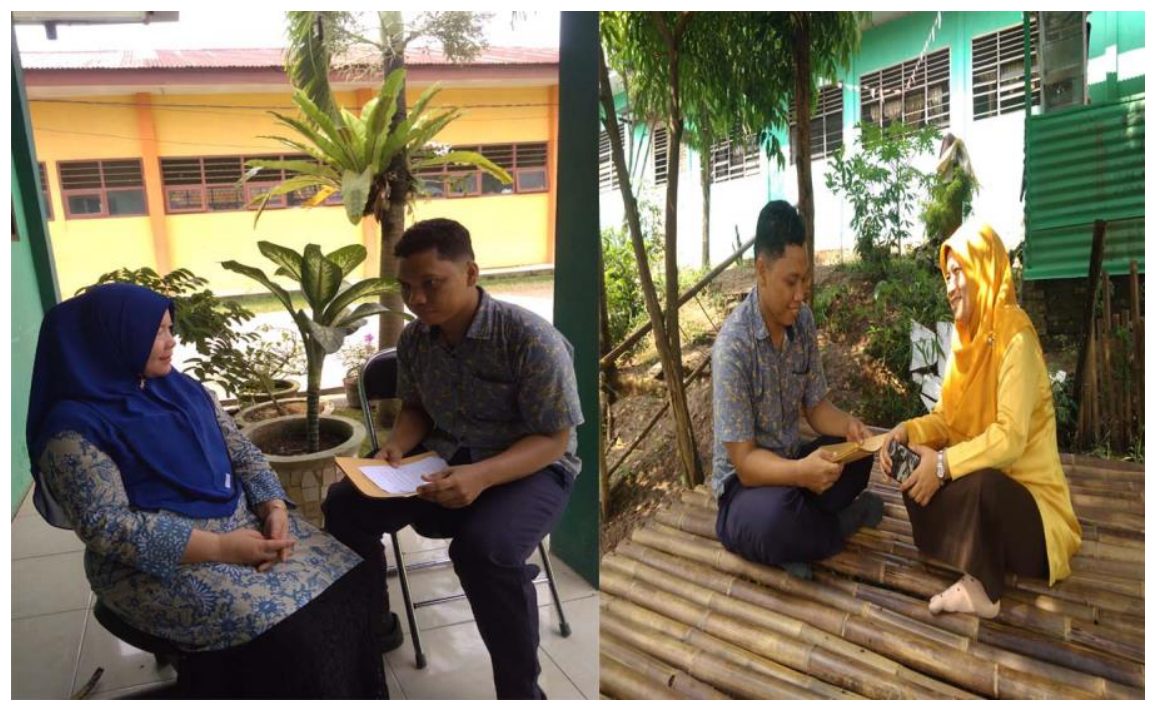


As an education leader in a madrasah, a madrasah principal must also have actions that can motivate all madrasah citizens to make a change for the better. Similarly, the actions taken by the Head of MAN 3 Medan are as follows: (1). performance, where a leader must set a good example to all madrasah personnel with good behavior, attractive appearance, but also must be balanced with a good heart so that good behavior also follows; (2) professional, namely the head of the madrasa also provides an example by doing work and duties seriously. It is expected that all madrasah personnel can work professionally in their respective duties; and (3) procedural, is an activity in which doing a job must be following agreed procedures/rules. This activity can also be said that in a madrasah bureaucracy, it must go through several stages to get to the head of the madrasah. The principal of madrasah in motivating madrasa citizens also shows his role as an agent of change by continuing his education to the Doctoral level, when someone wants to make changes, the first thing that must be done is to change oneself, to successfully change the organization, society and even the world begins with successfully changing oneself. The individual is the pillar when we want to be the pillar of that change. The head of MAN 3 Medan shows that education does not stop at level 2 only. It is not just a title that is sought after today, but how to obtain new insights, information, and knowledge to be disseminated to the madrasa community. Besides that, the head of MAN 3 Medan also showed how to manage the tasks carried out by the state, individual, family, and organizational tasks.

The results showed that the head of the madrasah was the determinant of the formulation contained in a madrasah itself. Efforts made in increasing the professional competence of teachers by holding seminars and inviting competent speakers are carried out for the active role of the Subject Teacher Conference (Arifin, 2019). Furthermore, it is also explained (Sutikat, 2017) from the results of the research that MGMP is an association forum for subject teachers to communicate, learn and exchange ideas and experiences to increase motivation, frequency, intensity, professionalism, and performance. (Pratama et al., 2018) The existence of MGMP to train teachers in learning and IT development, evaluation in the form of measuring performance, attitudes, work results, and self-assessment consistently, systematically and programmed. (Somantri et al., 2019) the training system is carried out to increase skills and knowledge as well as understanding the use of alternative learning media that can be used in the learning process in the classroom. (Bahrissalim \& Fauzan, 2018) Mention that the curriculum training held can improve pedagogical competencies such as cognitive abilities, preparation of lesson plans, and implementation of learning that are already in good categories. A form of effort that can be done as an effort to increase teacher professionalism is by carrying out innovative learning activities, developing knowledge and insight (Kristiawan \& Rahmat, 2018)

The results of research by (Julaiha \& Maula, 2019) that the implementation of the Adiwiyata Madrasah, which began in 2015, has succeeded in obtaining achievements at the provincial level in 2017, the implementation of the Adiwiyata Madrasah program aims to make the human resources owned by the madrasah grow more Islamic aqidah, have a noble character, are smart, independent, competitive and able to work together and care about the environment. The program operates with 4 policies, namely; environmentally based curriculum, environmentally sound policies, participatory activities, and the use of environmentally-friendly infrastructure. Another study states that to realize the Adiwiyata madrasah program, namely by conducting workshops, as evidenced by the collaboration with the PGMI UM 
Magelang study program, the chairman of the Muhammadiyah branch, the head of MI failure by committing and giving statements to preserve the environment. In its implementation, the madrasah applies the multi-directional circle model in madrasah ibtidaiyah adiwiyata, which is very effective because it can foster a spirit of cooperation and develop the potential of non-academic fields for all madrasah components such as school principals, teachers, students, committees, and the Magelang environmental agency (Oktradiksa \& Sari, 2017). Research by (McDermott et al., 2011) on the study of health education in schools, there are about 1,100 primary schools and 350 secondary schools. The SHES team is involved in development through a conceptual approach to health education (physical, mental, and social). The socialization of health education is carried out to open the eyes of the importance of health, health is related to subjects such as mathematics and language by integrating it into the existing curriculum, health education is seen as a broader component, not only in the school area but also in the community as well. Adiwiyata management activities are carried out in stages such as planning, organizing, actuating, and controlling. Planning is defined as the process of forming a team, holding meetings to organize activities, organizing all components of the internal and external environment of the madrasah such as the Environmental Agency (DLH), the surrounding community, stakeholders, other agencies, and the madrasah itself. Actuating is characterized by a concrete form of implementation of Adiwiyata activities which can also be in the form of activities of guidance, coaching, the direction of each program, integrated from subjects and routines. Controlling is an activity that is directly carried out by the head of a madrasah, usually by monitoring, evaluating, and surveying (Chamidah, 2020; Diyan Nurvika Kusuma Wardani, 2020; Nurhadi \& Irfaida, 2019). The implementation of the Adiwiyata program at MIN Tegalasri Blitar is based on environmentally friendly policies, environmentally-based curricula, participatory environmental activities, and facilities that are environmentally friendly supporters. Also, efforts are made so that the program can run smoothly by socializing the main activities to students so that students understand and understand so that an agreement can be formed for an environmentally sound school (Landriany, 2014; Majid \& Rochman, 2014). An environment-based curriculum can be done by mapping basic competencies to be used as indicators, implementation, and delivery of any material that is integrated with the environment, communicating with stakeholders to apply the curriculum by making annual planning and improving the quality of students who are oriented to the surrounding environment (Atiqoh \& Saputro, 2017).

The results of the study (Park \& Rainey, 2012) show that intrinsic motivation has a close relationship with the effectiveness of an organization, job involvement, perceptions in the bureaucracy, socialization, and communication. When a public manager is more involved in various existing social communications, eating will have a positive impact on the organizational unit. The results of survey research conducted in Turkey involving 327 teachers who teach in public elementary schools show that leadership has an influence on teacher professionalism, teacher trust and motivation received can mediate the leadership of a school principal, thus proving that there is a positive relationship between distributed leadership. with teacher professionalism (Bektaş et al., 2020). Research from (Finnigan, 2010) shows that instructional leadership from school principals fosters expectations for teachers, expectations such as gaining experience (empirical), continuing education, improving performance, and also changing behavior. With the hope of the teacher, it is hoped that the school will be able to get out of the pilot policies of the government. 
The motivation given by a madrasah principal will have a good impact on teachers, the form of efforts made such as providing incentives for teachers, providing training and facilitating teachers to attend teacher deliberations in the field of study so that the quality of education in madrasah can improve (Kaspullah et al., 2020). Communication by positioning oneself on an equal footing with teachers, communication with body language (smiling, embracing and shaking hands) use communication media such as cellphones and having an attitude of loyalty as a factor in creating a good communication climate (Inah, 2016). Interpersonal communication is carried out as an effort to embrace the teacher as a whole and create a good communication culture and climate. When this can be done by a top leader in a school or madrasah, it will have a positive impact on teacher performance and other personal (Ritonga, 2020). The form of interpersonal communication carried out by the head of the madrasah is by combining internal communication within the organization, forms of communication such as downward communication and upward communication (Khairani et al., 2018).

So that the results of this research show that the leadership of the head of the madrasah is very important to improve the quality of education in MAN 3 Medan, the leadership that is applied as a measure of the progress of the madrasah. The implications are: (1) the implementation of competency education and training programs and curriculum innovation through the MGMP forum as a form of improving the quality and professionalism of teachers. (2) involving students in scientific trials and coaching extracurricular activities such as Nasyid and mushroom cultivation to add insight and soft skills to students. (3) the implementation of the Adiwiyata madrasah program as a forum for learning, environmental preservation, and awareness for all components in the madrasah. (4) interpersonal communication, two-way communication, and feedback as an effort to make interaction and communication run effectively. (5) motivate by exemplifying performance, professional, procedural, and agent of change. So it can be said that the important role of a leader in behaving and pouring out his ideas for advancing madrasas.

The results of this study can be used as a reference for madrasah/school principals who want to improve the quality of their madrasah citizens, MGMP activities for teachers as professional support, improve student achievement in their curricular and extracurricular pieces, carry out the Adiwiyata program as a form of environmental preservation. The head of the madrasa as a leader is naturally angry about communicating, therefore communication must be maintained properly, for that it is necessary to carry out interpersonal communication. Also, motivational encouragement for all components in madrasah must be right on target so that the planned programs can run well and be implemented.

\section{CONCLUSION}

The leadership of the head of the madrasah is the key to the success of all activities, the programs in the madrasah, the madrasah will come alive if the leader/principal of the madrasah can collaborate with all madrasah members with effective communication, policies that provide opportunities for teachers to participate in contributing thoughts, being creative, innovating and not hindering to continue to develop into supporting factors for improving the quality of education in MAN 3 Medan. The quality of education in madrasas continues to be improved through training programs for teachers, both competency training, and curriculum innovation carried out by madrasah through the MGMP forum, as well as always motivating for 
madrasah members to carry out the vision, mission, and goals outlined in the programs madrasa work. Furthermore, the form of efforts made to improve the quality of education is to develop the scientific potential of students by including science grants. Students are also given soft skill knowledge through extracurricular activities, namely "nasyid", mushroom cultivation, and training students to be directly involved in entrepreneurship. Not only that, but the principal of madrasah through his program also created a living pharmacy and an adiwiyata madrasah environment to realize awareness of the importance of the environment, collaborating subjects by orienting towards adiwiyata madrasas as an effort to make the program successful. In interacting with teachers and other school components the principal of the madrasah also carries out interpersonal, two-way communication and feedback to streamline the information conveyed. Also, the form of motivation for teachers and students is given by the principal by good reflecting, professional behavior and obeying procedures in all fields of work and organizations.

\section{ACKNOWLEDGMENT}

The author thank to Nurkholidah, S.Pd.I., M.Pd as the principal of the MAN 3 Medan madrasah who has allowed the author to research in the madrasah and also provides information about madrasah activities. Thanks also to Atfaiyah Harahap, S.Pd., M.Si, and other teachers who have taken their time with the author.

\section{AUTHOR CONTRIBUTION STATEMENT}

The author participated in this research and approved the final text of the study.

\section{REFERENCES}

Achmad, A. K. (2016). Kepemimpinan Kepala Sekolah Dalam Meningkatkan Mutu Pendidikan. JMPI, 1(2), 115-126. http://ejournal.uinmalang.ac.id/index.php/jmpi/article/view/3957

Arifin, A. (2019). The Role of MGMP Civic Education in Improving Professional Competence of Teacher. Jurnal Iqra': Kajian Ilmu Pendidikan, 4(2), 249-264. https:// doi.org/10.25217/ji.v4i2.557

Atiqoh, L., \& Saputro, B. (2017). Kurikulum Pendidikan Agama Islam Berbasis Lingkungan Sebagai Penguatan Pendidikan Humanistik Di Sekolah Adiwiyata. Edukasia: Jurnal Penelitian Pendidikan Islam, 12(2), 285. https:// doi.org/10.21043/edukasia.v12i2.2492

Bahrissalim, \& Fauzan. (2018). Evaluasi Kurikulum Pelatihan Dalam Meningkatkan Kompetensi Pedagogik Guru Pai Di Balai Diklat Keagamaan Jakarta. Edukasia: Jurnal Penelitian Pendidikan Islam, 13(1), 25-52. https://journal.iainkudus.ac.id/index.php/Edukasia/article/view/2779

Bektaş, F., Kılınç, A. Ç., \& Gümüş, S. (2020). The effects of distributed leadership on teacher professional learning: mediating roles of teacher trust in principal and teacher motivation. Educational Studies, 1-23. https:// doi.org/10.1080/03055698.2020.1793301

Chamidah, N. (2020). Implementasi Konsep Madrasah Berwawasan Lingkungan (Studi Kasus di MAN Purworejo). Cakrawala, 4(1). https:// doi.org/https:// doi.org/10.12345/cakrawala.v4i1.217

Diyan Nurvika Kusuma Wardani. (2020). Analisis Implementasi Program Adiwiyata dalam Membangun Karakter Peduli Lingkungan. Southeast Asian Journal of Islamic Education Management, 1(1), 60-73. https:/ / doi.org/10.21154/sajiem.v1i1.6 
Fadhli, M. (2019). Pengaruh Kepemimpinan Kepala Madrasah dan Komitmen Guru Terhadap Efektifitas Madrasah di Lhokseumawe. Jurnal Iqra': Kajian Ilmu Pendidikan, 4(1), 56-70. https:// doi.org/10.25217/ji.v4i1.447

Finnigan, K. S. (2010). Principal Leadership and Teacher Motivation under High-Stakes Accountability Policies. Leadership and Policy in Schools, 9(2), 161-189. https:// doi.org/10.1080/15700760903216174

Fitrah, M. (2017). Peran Kepala Sekolah Dalam Meningkatkan Mutu Pendidikan. Jurnal Penjaminan Mutu, 3(1), 31. https:/ / doi.org/10.25078/jpm.v3i1.90

Gurova, G., Piattoeva, N., \& Takala, T. (2015). Quality of Education and Its Evaluation: An Analysis of the Russian Academic Discussion. European Education, 47(4), 346364. https:// doi.org/10.1080/10564934.2015.1107377

Hasibuan, A. I., Mustapid, M., \& Wijaya, C. (2019). Peran Kepemimpinan Kepala Madrasah dalam Meningkatkan Mutu Pendidikan di MTs. Swasta Miftahul Falah Sunggal Kabupaten Deli Serdang. Anthropos: Jurnal Antropologi Sosial Dan Budaya (Journal of Social and Cultural Anthropology), 4(2), 201. https:// doi.org/10.24114/antro.v4i2.12024

Husaini, U. (2011). Manajemen. Bumi Aksara.

Inah, E. N. (2016). Pola Komunikasi Interpersonal Kepala Madrasah Tsanawiyah Tridana Mulya Kecamatan Landono Kabupaten Konawe Selatan. Al- Ta'dib : Jurnal Kajian Ilmu Kependidikan, 9(2). https://doi.org/http:/ /dx.doi.org/10.31332/atdb.v9i2.519

Jones, M., Adams, D., Hwee Joo, M. T., Muniandy, V., Perera, C. J., \& Harris, A. (2015). Contemporary challenges and changes: principals' leadership practices in Malaysia. Asia Pacific Journal of Education, 35(3), 353-365. https:// doi.org/10.1080/02188791.2015.1056591

Julaiha, S., \& Maula, I. (2019). Implementasi Manajemen Madrasah Adiwiyata di MAN 1 Samarinda. Manageria: Jurnal Manajemen Pendidikan Islam, 3(2), 353-367. https:// doi.org/10.14421/manageria.2018.32-08

Kaspullah, Putra, P., \& Wulandari, I. (2020). Pengaruh Persepsi Guru Terhadap Kepemimpinan Kepala Madrasah, Motivasi Kerja Dan Kompetensi Guru Terhadap Kinerja Guru Di Madrasah Tsanawiyah Negeri Se-Kabupaten Sambas. Jurnal Inspiratif Pendidikan Is Published and Managed, 9(2). https:// doi.org/https:// doi.org/10.24252/ip.v9i2.16033

Khairani, I., Efendi, E., \& Saputra, E. (2018). Komunikasi Interpersonal Kepala Madrasah Dalam Meningkatkan Kinerja Guru Di Madrasah Aliyah Negeri 1 Aceh Timur. Edu-Riligia: Jurnal Ilmu Pendidikan Islam Dan Keagamaan, 2(3). https:// doi.org/http:/ / dx.doi.org/10.47006/er.v2i3.1837

Krisbiyanto, A. (2019). Efektifitas Kepemimpinan Kepala Madrasah terhadap Mutu Pendidikan MTsN 2 Mojokerto. Nidhomul Haq : Jurnal Manajemen Pendidikan Islam, 4(1), 52-69. https://doi.org/10.31538/ndh.v4i1.182

Kristiawan, M., \& Rahmat, N. (2018). Peningkatan Profesionalisme Guru Melalui Inovasi Pembelajaran. Jurnal Iqra': Kajian Ilmu Pendidikan, 3(2), 373-390. https://journal.iaimnumetrolampung.ac.id/index.php/ji/article/view/348/27

Landriany, E. (2014). Implementasi Kebijakan Adiwiyata Dalam Upaya Mewujudkan Pendidikan Lingkungan Hidup di SMA Kota Malang. Jurnal Kebijakan Dan Pengembangan Pendidikan, https://doi.org/https://doi.org/10.22219/jkpp.v2i1.1739 2(1).

Liu, S., \& Hallinger, P. (2018). Instructional, Principal Leadership, Teacher Self-Efficacy, and Teacher Learning, Professional A, in China: Testing Model, Mediated-Effects. 
Educational

Administration

Quarterly,

$1-28$.

https://journals.sagepub.com/doi/10.1177/0013161X18769048

Majid, A., \& Rochman, C. (2014). Pendekatan Ilmiah dalam Implementasi Kurikulum. PT Remaja Rosdakarya. Google Scholar

Makawimbang, J. H. (2012). Kepemimpinan Pendidikan yang Bermutu. Alfabeta.

Maryati. (2016). Pola Kepemimpinan Kepala Madrasah Dalam Meningkatkan Mutu Pendidikan Di Mts Nurul Qur'an Tegalweropucakwangi Pati. Quality, 1(2), 164181. https://doi.org/http://dx.doi.org/10.21043/quality.v4i1.2119

McDermott, R. J., Mayer, A. B., \& The School Health Education Study F. (2011). The School Health Education Study +50 Years. American Journal of Health Education, 42(6), 330-348. https://doi.org/10.1080/19325037.2011.10599205

Miller, R. J., Goddard, R. D., Kim, M., Jacob, R., Goddard, Y., \& Schroeder, P. (2016). Development Improve School Leadership? Results From a Randomized Control Trial Assessing the Impact of McREL's Balanced Leadership Program on Principals in Rural Michigan Schools. Educational Administration Quarterly, 1-36. https://journals.sagepub.com/doi/10.1177/0013161X16651926

Mulyasa. (2013). Manajemen dan Kepemimpinan Kepala Sekolah. Bumi Aksara.

Nur, M. (2016). Manajemen Madrasah dalam Meningkatkan Mutu Pendidikan. Administrasi Pendidikan, 4(1), 91-103. http://jurnal.unsyiah.ac.id/JAP/article/view/2611/2465

Nurhadi, A., \& Irfaida, I. (2019). Kerja Sama Kelembagaan Pada Madrasah Adiwiyata Di Mts Negeri 2 Pamekasan. Re-JIEM (Research Journal of Islamic Education Management), 1(2), 01. https:/ / doi.org/10.19105/rjiem.v1i2.2087

Oktradiksa, A.-, \& Sari, K. P. (2017). Implementasi Multi-Directional Circle Model dalam Mewujudkan Madrasah Ibtidaiyah Adiwiyata di Kabupaten Magelang. Al $\begin{array}{lllll}\text { Ibtida: Jurnal Pendidikan Guru } & 153 .\end{array}$ https:// doi.org/10.24235/al.ibtida.snj.v4i2.1727

Park, S. M., \& Rainey, H. G. (2012). Work motivation and social communication among public managers. The International Journal of Human Resource Management, 23(13), 2630-2660. https:/ / doi.org/10.1080/09585192.2011.637060

Pratama, S., Yusrizal, \& Niswanto. (2018). Manajemen Musyawarah Guru Mata Pelajaran Pendidikan Agama Islam Dalam Peningkatan Profesional Guru Pada Forum Mgmp Smk Di Kabupaten Aceh Jaya. Jurnal Administrasi Pendidikan, 6(1), 24-29. http://www.jurnal.unsyiah.ac.id/JAP/article/download/11735/9294

Ritonga, B. (2020). Pengaruh Komunikasi Interpersonal, Gaya Kepemimpinan, Budaya Organisasi Terhadap Kinerja Guru Di MAN 2 Model. EduTech: Jurnal Ilmu Pendidikan Dan Ilmu Sosial, https:// doi.org/https:// doi.org/10.30596/edutech.v6i2.4930

Said, A. (2018). Kepemimpinan Kepala Sekolah Dalam Melestarikan Budaya Mutu Sekolah. Journal Evaluasi, 2(1), 257. https:/ / doi.org/10.32478/evaluasi.v2i1.77

Saifulloh, M., Muhibbin, Z., \& Hermanto. (2012). Strategi Peningkatan Mutu Pendidikan Di Sekolah. Jurnal Sosial Humaniora, 5(2), 206-218. http://www.iptek.its.ac.id/index.php/jsh/article/download/619/341

Somantri, O., Abidin, T., Wijayanto, S., Wibowo, D. S., \& Dairoh. (2019). Peningkatan Kompetensi Guru Melalui Pelatihan Keterampilan Pembuatan E Presentation. Solma, $8(2)$, 219-228.

https://journal.uhamka.ac.id/index.php/solma/article/view/3245/1149

Sugiyono. (2016). Metode Penelilitian Kuantitatif dan Kualitatif dan RED. Alfabeta. 
Sutikat. (2017). Manajemen Musyawarah Guru Mata Pelajaran (Mgmp) Dalam Meningkatkan Profesionalisme Guru Akidah Akhlak Mts Negeri Di Kabupaten Kudus Tahun Pelajaran 2015/2016. Quality, 5(2), 286-306. https://journal.iainkudus.ac.id/index.php/Quality/article/download/3063/239 7

Triyatna, Deni Kuswara, C. (2012). Manajemen Pendidikan. Alfabeta.

Yunus, M. (2016). Profesionalisme Guru Dalam Peningkatan Mutu Pendidikan. Lentera Pendidikan: Jurnal Ilmu Tarbiyah Dan Keguruan, 19(1), 112-128. https:// doi.org/10.24252/lp.2016v19n1a10

\section{Copyright Holder :}

(c) Zaini, .M., \& Syafaruddin, S. (2020).

First Publication Right :

(C) Jurnal Iqra' : Kajian Ilmu Pendidikan

This article is under:

(ㄷ)(1) (2) 